\title{
ESTIMASI MODEL PERSAMAAN SIMULTAN DENGAN METODE TWO STAGE LEAST SQUARE (2SLS)
}

\author{
Misno, Evy Sulistianingsih
}

\begin{abstract}
INTISARI
Kemiskinan adalah keadaan dimana seorang individu atau sekelompok orang tidak mampu memenuhi kebutuhan dasarnya. Pengangguran merupakan keadaan seseorang yang tergolong dalam angkatan kerja yang ingin mendapatkan pekerjaan, tetapi belum dapat mendapatkan pekerjaan tersebut. Penelitian ini bertujuan untuk mengkaji model persamaan simultan pada analisis kemiskinan dan pengangguran dengan metode 2SLS. Data yang digunakan merupakan data sekunder yang diperoleh dari Badan Pusat Statistik (BPS) tahun 2016. Model persamaan simultan merupakan himpunan persamaan yang terdiri lebih dari satu variabel tak bebas dan lebih dari satu persamaan yang saling terkait. Metode 2SLS merupakan perluasan dari metode OLS yang termasuk kedalam kelompok analisis persamaan struktural. Dari hasil pengujian terdapat hubungan antar variabel kemiskinan dan pengangguran. Hasil estimasi parameter pada model simultan persamaan kemiskinan menunjukkan bahwa variabel pengangguran dan IPM berpengaruh signifikan terhadap kemiskinan. Hasil estimasi parameter pada model simultan persamaan pengangguran menunjukkan bahwa kemiskinan dan jumlah penduduk berpengaruh signifikan terhadap pengangguran.
\end{abstract}

Kata Kunci: Model Persamaan Simultan, Metode 2SLS, Kemiskinan, Pengangguran

\section{PENDAHULUAN}

Pengangguran adalah istilah bagi orang yang tidak memiliki pekerjaan, sedang mencari kerja atau seseorang yang sedang mencari pekerjaan yang layak [1]. Pengangguran merupakan masalah yang serius dalam bidang perekonomian. Dengan adanya pengangguran, produktivitas dan pendapatan masyarakat berkurang yang menyebabkan timbulnya kemiskinan dan masalah sosial lainnya. Kemiskinan adalah keadaan dimana seseorang tidak mampu memenuhi kebutuhan dasar hidup seperti makanan, pakaian, tempat berlindung, pendidikan dan kesehatan [1]. Secara teori, apabila seseorang memiliki pekerjaan dan penghasilan diharapkan dapat memenuhi kebutuhan dasar hidup. Apabila kebutuhan dasar hidup terpenuhi maka, jumlah penduduk miskin berkurang. Sebaliknya, apabila tingkat pengangguran rendah maka tingkat kemiskinan juga rendah. Dengan berkurangnya jumlah penduduk miskin maka tingkat pengangguran juga berkurang.

Faktor-faktor yang mempengaruhi hubungan kemiskinan dan pengangguran dapat dimodelkan dalam model persamaan simultan. Model persamaan simultan merupakan model persamaan yang terdiri lebih dari satu variabel tak bebas dan lebih dari satu persamaan. Model persamaan simultan memiliki ciri-ciri tertentu dimana variabel tak bebas dalam satu persamaan bisa muncul sebagai variabel bebas dalam persamaan lain [2]. Akibatnya, variabel tak bebas berkorelasi dengan error dari persamaan dimana variabel tersebut muncul sebagai variabel bebas. Apabila metode OLS diterapkan dalam menaksir parameter model persamaan simultan, maka penaksir yang diperoleh tidak konsisten, sebab salah salu asumsi dari metode OLS adalah variabel bebas tidak berkorelasi dengan error [3]. Oleh karena itu, dalam menaksir parameter dalam model persamaan simultan digunakanlah metode 2SLS.

Metode 2SLS merupakan metode yang digunakan dalam menaksir parameter model persamaan simultan. Metode ini digunakan untuk mengganti metode OLS yang disebabkan adanya korelasi antara variabel bebas endogennya dan error. Metode 2SLS mempunyai dua langkah perhitungan. Langkah pertama adalah membentuk persamaan reduksi untuk membuang korelasi yang terjadi antara variabel bebas endogennya dengan error, sehingga diperoleh nilai taksirannya yaitu $\widehat{Y}_{i}$. Persamaan reduksi adalah persamaan setiap variabel endogen dengan semua variabel eksogennya. Langkah kedua 
adalah mensubstitusi variabel $Y_{i}$ pada model struktural dengan variabel $\widehat{Y}_{i}$ kemudian menggunakan metode OLS. Tujuan dari penelitian ini adalah untuk mengkaji pembentukan model persamaan simultan dengan menerapkannya pada analisis hubungan kemiskinan dan pengangguran dengan metode 2SLS.Penelitian ini hanya membahas data kemiskinan dan pengangguran serta faktor-faktor yang mempengaruhinya yaitu IPM dan jumlah penduduk di Kabupaten/Kota dipulau Kalimantan tahun 2016 dengan metode 2SLS. Langkah-langkah dalam penelitian ini adalah pengumpulan dan penyajian data model struktural kemiskinan dan pengangguran, identifikasi model dengan kondisi order dan rank dan melakukan estimasi model persamaan simultan dengan metode 2SLS.

\section{MODEL PERSAMAAN SIMULTAN}

Model persamaan simultan merupakan model persamaan yang terdiri lebih dari satu variabel tak bebas dan lebih dari satu persamaan yang saling terkait [2]. Singkatnya, suatu variabel memiliki dua peranan sekaligus yaitu sebagai variabel bebas dan sebagai variabel tak bebas yang disebut dengan variabel endogen dan variabel eksogen sebagai variabel bebas dalam model persamaan simultan. Secara umum, bentuk persamaan struktural dari model persamaan simultan sebagai berikut [4].

dimana:

$$
\begin{array}{ccc}
Y_{1}= & \alpha_{12} Y_{2}+\alpha_{13} Y_{3}+\cdots+\alpha_{1 m} Y_{m}+\beta_{11} X_{1}+\beta_{12} X_{2}+\cdots+\beta_{1 k} X_{i}+\varepsilon_{1} \\
Y_{2}=\alpha_{21} Y_{1}+\alpha_{23} Y_{3}+\cdots+\alpha_{2 m} Y_{m}+\beta_{21} X_{1}+\beta_{22} X_{2}+\cdots+\beta_{2 k} X_{i}+\varepsilon_{2} \\
Y_{3}=\alpha_{31} Y_{1}+\alpha_{32} Y_{2} & +\cdots+\alpha_{3 m} Y_{m}+\beta_{31} X_{1}+\beta_{32} X_{2}+\cdots+\beta_{3 k} X_{i}+\varepsilon_{3} \\
\vdots & \vdots & \vdots \\
Y_{i}=\alpha_{i 1} Y_{1}+\alpha_{i 2} Y_{2} & +\cdots+\alpha_{i, i-1} Y_{m}+\beta_{i 1} X_{1}+\beta_{i 2} X_{2}+\cdots+\beta_{i} X_{i}+\varepsilon_{i}
\end{array}
$$

$Y_{1}, Y_{2}, \ldots, Y_{i}=$ Variabel endogen ke- $i$ untuk $i=1,2, \ldots, m$

$X_{1}, X_{2}, \ldots, X_{i}=$ Variabel eksogen ke- $i$ untuk $i=1,2, \ldots, n$

$\varepsilon_{1}, \varepsilon_{2}, \ldots, \varepsilon_{i}=$ Error ke-i untuk $i=1,2, \ldots, m$

$\alpha, \beta=$ Koefesien parameter

\section{IDENTIFIKASI MODEL PERSAMAAN SIMULTAN}

Aturan identifikasi model persamaan simultan dilakukan melalui dua cara yaitu, dengan kondisi order dan rank. Kemungkinan yang terjadi dari identifikasi model persamaan simultan yaitu, tidak teridentifikasi, tepat teridentifikasi dan terlalu teridentifikasi. Berdasarkan kondisi order model persamaan simultan dikatakan teridentifikasi apabila semua persamaan struktural memenuhi syarat berikut ini:

$$
K-k \geq m-1
$$

Apabila $K-k=m-1$ dikatakan model persamaan simultan "tepat teridentifikasi"

Apabila $K-k>m-1$ dikatakan model persamaan simultan "terlalu teridentifikasi" dimana:

$M=$ Jumlah semua variabel endogen dalam model persamaan simultan

$m=$ Jumlah variabel endogen dalam persamaan tertentu

$K=$ Jumlah semua variabel eksogen dalam model persamaan simultan

$k=$ Jumlah variabel eksogen dalam persamaan tertentu

Kondisi order hanya kondisi yang diperlukan, namun belum cukup menunjukkan kondisi identifikasi yang sebenarnya. Artinya, walaupun dalam kondisi order persamaan teridentifikasi, ada kemungkinan persamaan tersebut tidak teridentifikasi apabila diuji dengan kondisi rank. Menurut kondisi rank, model persamaan simultan dikatakan teridentifikasi apabila dapat dibentuk satu determinan bukan nol dari koefesien variabel yang tidak terdapat dalam persamaan tersebut, namun terdapat dalam persamaan lain dalam model persamaan simultan. Model persamaan simultan dikatakan teridentifikasi apabila memenuhi syarat kondisi order dan rank [2]. 


\section{METODE TWO STAGE LEAST SQUARE (2SLS)}

Metode 2SLS adalah salah satu metode regresi yang termasuk kedalam kelompok analisis persamaan struktural. Metode 2SLS merupakan perluasan dari metode OLS yang biasa digunakan dalam perhitungan analisis regresi. Metode 2SLS digunakan ketika terjadi korelasi antara variabel bebas dengan error. Ide dasar metode 2SLS adalah menghilangkan korelasi yang terjadi antara variabel bebas dengan error. Bentuk umum persamaan struktural ke-i sebagai berikut:

$$
Y_{i}=\alpha_{i 1} Y_{1}+\alpha_{i 2} Y_{2}+\cdots+\alpha_{i m} Y_{m}+\beta_{i 1} X_{1}+\cdots+\beta_{i k} X_{k}+\varepsilon_{i}
$$

Langkah-langkah penyelesaiaan metode 2SLS dibagi dalam dua langkah sebagai berikut [4]:

1. Menggunakan metode OLS pada persamaan reduksi. Persamaan reduksi adalah persamaan setiap variabel endogen dengan semua variabel eksogen

$$
\begin{aligned}
& Y_{1}=\pi_{11} X_{1}+\pi_{12} X_{2}+\cdots+\pi_{1 k} X_{k}+\varepsilon_{1} \\
& Y_{2}=\pi_{21} X_{1}+\pi_{22} X_{2}+\cdots+\pi_{2 k} X_{k}+\varepsilon_{2} \\
& Y_{i}=\pi_{i 1} X_{1}+\pi_{i 2} X_{2}+\cdots+\pi_{i k} X_{k}+\varepsilon_{i}
\end{aligned}
$$

diperoleh:

$$
\begin{aligned}
& \hat{Y}_{1}=\pi_{11} X_{1}+\pi_{12} X_{2}+\cdots+\pi_{1 k} X_{k} \\
& \hat{Y}_{2}=\pi_{21} X_{1}+\pi_{22} X_{2}+\cdots+\pi_{2 k} X_{k} \\
& \vdots \quad \vdots \quad \vdots \quad \vdots \quad \vdots \\
& \hat{Y}_{i}=\pi_{i 1} X_{1}+\pi_{i 2} X_{2}+\cdots+\pi_{i k} X_{k}
\end{aligned}
$$

sehingga persamaan simultan dapat dinyatakan sebagai

$$
\begin{aligned}
& Y_{1}=\hat{Y}_{1}+\varepsilon_{1} \\
& Y_{2}=\hat{Y}_{2}+\varepsilon_{2}
\end{aligned}
$$

$$
Y_{i}=\hat{Y}_{i}+\varepsilon_{i}
$$

2. Variabel endogen yang muncul disisi kiri pada persamaan struktural diganti dengan persamaan $Y_{i}=\hat{Y}_{i}+\varepsilon_{i}$ dan memperoleh persamaan sebagai berikut:

$$
\begin{aligned}
& Y_{i}=\alpha_{i 1}\left(\hat{Y}_{1}+\varepsilon_{1}\right)+\alpha_{i 2}\left(\hat{Y}_{2}+\varepsilon_{2}\right)+\cdots+\alpha_{i m}\left(\hat{Y}_{i}+\varepsilon_{i}\right)+\beta_{i 1} X_{1}+\cdots+\beta_{i k} X_{k}+\varepsilon_{i} \\
& Y_{i}=\alpha_{i 1} \hat{Y}_{1}+\alpha_{i 1} \varepsilon_{1}+\alpha_{i 2} \hat{Y}_{2}+\alpha_{i 2} \varepsilon_{2}+\cdots+\alpha_{i m} \hat{Y}_{i}+\alpha_{i m} \varepsilon_{i}+\beta_{i 1} X_{1}+\cdots+\beta_{i k} X_{k}+\varepsilon_{i} \\
& Y_{i}=\alpha_{i 1} \hat{Y}_{1}++\alpha_{i 2} \hat{Y}_{2}+\cdots+\alpha_{i m} \hat{Y}_{i}+\beta_{i 1} X_{1}+\cdots+\beta_{i k} X_{k}+\varepsilon^{*}{ }_{i} \\
& \text { Dimana: } \varepsilon^{*}{ }_{i}=\varepsilon_{i}+\alpha_{i 1} \varepsilon_{1}+\alpha_{i 2} \varepsilon_{2}+\alpha_{i m} \varepsilon_{i}
\end{aligned}
$$

\section{MODEL SIMULTAN 2SLS KEMISKINAN DAN PENGANGGURAN}

\section{Data}

Data yang digunakan dalam penelitian ini merupakan data sekunder yang diperoleh dari BPS Provinsi setiap Pulau di Kalimantan, yang meliputi data kemiskinan $\left(Y_{1}\right)$, pengangguran $\left(Y_{2}\right)$, Indeks Pembangunan Manusia $\left(X_{1}\right)$ dan jumlah penduduk $\left(X_{2}\right)$. Model persamaan simultan dalam penelitian ini terdiri dari persamaan kemiskinan dan pengangguran. Bentuk persamaan struktural kemiskinan dan pengangguran sebagai berikut:

$$
\begin{aligned}
& Y_{1}=\alpha_{10}+\alpha_{11} Y_{2}+\beta_{11} X_{1}+\varepsilon_{1} \\
& Y_{2}=\alpha_{11}+\alpha_{12} Y_{1}+\beta_{12} X_{2}+\varepsilon_{2}
\end{aligned}
$$




\section{Identifikasi Kondisi Order dan Rank}

Menurut kondisi order persamaan struktural dari model persamaan simultan dikatakan teridentifikasi apabila jumlah variabel eksogen yang tidak dimasukkan dalam persamaan, sekurangkurangnya harus sebanyak jumlah variabel endogen yang terdapat dalam model dikurangi satu. Hasil identifikasi dengan kondisi order sebagai berikut:

Tabel 4.1 Kondisi Order

\begin{tabular}{lcccccc}
\hline Persamaan & $K$ & $k$ & $K-k$ & $M$ & $M-1$ & Keterangan \\
\hline Kemiskinan & 2 & 1 & 1 & 2 & 1 & Tepat Teridentifikasi \\
\hline Pengangguran & 2 & 1 & 1 & 2 & 1 & Tepat Teridentifikasi \\
\hline
\end{tabular}

Berdasarkan Tabel 4.1 diketahui bahwa persamaan struktural teridentifikasi sehingga dapat dikatakan bahwa kondisi order terpenuhi.

Model persamaan simultan dikatakan teridentifikasi apabila memenuhi syarat kondisi order dan rank. Menurut kondisi rank, model persamaan simultan dikatakan teridentifikasi apabila dapat dibentuk satu determinan bukan nol dari koefesien variabel yang tidak terdapat dalam persamaan tersebut, namun terdapat dalam persamaan lain dalam model persamaan simultan.

\section{Tabel 4.2 Kondisi Rank}

\begin{tabular}{lccccc}
\hline Persamaan & Konstanta & $Y_{1}$ & $Y_{2}$ & $X_{1}$ & $X_{2}$ \\
\hline Kemiskinan & $\alpha_{10}$ & 1 & $\alpha_{11}$ & $\beta_{11}$ & 0 \\
\hline Pengangguran & $\alpha_{11}$ & $\alpha_{12}$ & 1 & 0 & $\beta_{12}$ \\
\hline
\end{tabular}

Berdasarkan Tabel 4.2 persamaan kemiskinan diketahui bahwa koefesien dari variabel $X_{2}=0$. Misalkan matriks dari koefesien variabel $X_{2}$ adalah matriks A dan dapat ditulis sebagai berikut:

$$
A=\left[\beta_{12}\right]
$$

Det $|A| \neq 0$ yang berarti persamaan kemiskinan merupakan persamaan yang teridentifikasi. Setelah diperoleh hasil identifikasi persamaan kemiskinan, selanjutnya dilakukan identifikasi persamaan pengangguran.

Berdasarkan Tabel 4.2 persamaan pengangguran diketahui bahwa koefesien dari variabel $X_{1}=0$. Misalkan matriks dari koefesien variabel $X_{1}$ adalah matriks B, sehingga matriks B dapat ditulis sebagai berikut:

$$
B=\left[\beta_{11}\right]
$$

Det $|B| \neq 0$ yang berarti persamaan pengangguran merupakan persamaan yang teridentifikasi. Berdasarkan identifikasi kondisi order dan rank diperoleh kesimpulan bahwa persamaan kemiskinan dan pengangguran teridentifikasi karena syarat kondisi order dan rank terpenuhi.

\section{Model Simultan 2SLS}

Hasil pemodelan persamaan simultan metode 2SLS pada persamaan kemiskinan dan pengangguran sebagai berikut:

$$
\begin{aligned}
& Y_{1}=2,568 \times 10^{-15}+1,086 Y_{2}-0,451 X_{1}+\varepsilon_{1} \\
& Y_{2}=1,681 \times 10^{-16}-0,590 Y_{1}+1,313 X_{2}+\varepsilon_{2}
\end{aligned}
$$

Pada persamaan kemiskinan diketahui nilai koefesien determinasi sebesar 0,673 , hal ini berarti variabel pengangguran dan IPM mampu menjelaskan variabel kemiskinan sebesar 67,3\%, sisanya sebesar 32,7\% dijelaskan oleh variabel lain yang tidak dimasukkan dalam persamaan. Pada uji F, diperoleh hasil estimasi nilai $\mathrm{F}_{\text {hitung }}$ sebesar 57,659 dan p-value sebesar 0,000. Karena nilai $\mathrm{F}_{\text {hitung }}>$ $\mathrm{F}_{\text {Tabel }}$ atau $p$-value $<5 \%$, maka dapat disimpulkan bahwa variabel eksogen pengangguran dan IPM 
secara bersama-sama telah berpengaruh signifikan terhadap variabel kemiskinan. Untuk Uji T, dapat dilihat pada pada $p$-value dari masing-masing variabel pengangguran dan IPM yang diperoleh pada Tabel 4.3, yaitu kurang dari $\alpha=5 \%$. Karena masing-masing variabel eksogen pengangguran dan IPM nilai $p$-value $<5 \%$, maka dapat disimpulkan variabel eksogen pengangguran dan IPM secara individu berpengaruh signifikan terhadap variabel kemiskinan.

Tabel 4.3 Hasil Estimasi Persamaan Simultan dengan Metode 2SLS

\begin{tabular}{llccc}
\hline \multirow{3}{*}{ Persamaan } & Variabel Eksogen & $\begin{array}{c}\text { Estimasi } \\
\text { Parameter }\end{array}$ & P-Value & R-Square \\
\hline \multirow{3}{*}{ Pemiskinan } & Konstanta & $2,568 \times 10^{-15}$ & & \\
\cline { 2 - 4 } & Pengangguran & 1,086 & 0,000 & \multirow{2}{*}{0,673} \\
\cline { 2 - 4 } & Ipm & 0,451 & 0,000 & \\
\cline { 2 - 4 } & Konstanta & $1,681 \times 10^{-16}$ & & \\
\cline { 2 - 4 } & Kemiskinan & $-0,59$ & 0,000 & \\
\cline { 2 - 4 } & Jumlah Penduduk & 1,313 & 0,000 & \\
\hline
\end{tabular}

Berdasarkan model simultan persamaan penganguran dengan metode 2SLS pada Tabel 4.3 terlihat, nilai koefisien determinasi sebesar 0,736, ini berarti variabel kemiskinan dan jumlah penduduk mampu menjelaskan variabel penangguran sebesar 73,6\%. Sisanya sebesar 26,4\% dijelaskan oleh variabel lain yang tidak dimasukkan dalam persamaan. Pada uji $\mathrm{F}$, diperoleh hasil estimasi nilai $\mathrm{F}_{\text {hitung }}$ sebesar 77,696 dan p-value sebesar 0,000. Karena nilai $\mathrm{F}_{\text {hitung }}>\mathrm{F}_{\text {tabel }}$ atau $p$-value < 5\%, maka dapat disimpulkan bahwa variabel eksogen kemiskinan dan jumlah penduduk secara bersama-sama berpengaruh signifikan terhadap variabel pengangguran. Untuk Uji T, dapat dilihat pada Tabel 4.3 bahwa nilai $p$-value dari variabel kemiskinan dan jumlah penduduk kurang dari $\alpha=5 \%$, maka dapat disimpulkan variabel eksogen kemiskinan dan jumlah penduduk secara individu berpengaruh signifikan terhadap variabel penganguran.

\section{Uji Asumsi Klasik}

Model simultan dikatakan baik apabila memenuhi beberapa asumsi klasik yaitu, nonheterokedastisitas, error berdistribusi normal dan non-multikolinieritas terpenuhi. Berikut adalah hasil uji dari asumsi-asumsi tersebut.

a. Uji Normalitas

Uji normalitas dilakukan untuk melihat kenormalan dari error. Pengujian hipotesis uji normalitas sebagai berikut:

$\mathrm{H}_{0}$ : Error berdistribusi normal

$\mathrm{H}_{1}$ : Error tidak berdistribusi normal

Pengujian normalitas dilakukan dengan mengunakan uji Kolmogorov-Smirnov. Berdasarkan output spss diperoleh nilai $p$-value persamaan kemiskinan dan pengangguran dari uji normalitas, masingmasing sebesar 0,223 dan 0,408 dimana lebih dari $\alpha=0,05$. Dengan demikian, $\mathrm{H}_{0}$ diterima yang berarti error dari persamaan kemiskinan dan pengangguran berdistribusi normal

b. Uji Multikolinieritas

Metode yang digunakan untuk mendeteksi adanya multikolinieritas dalam penelitian ini adalah dengan Variance Inflation Factor (VIF). Pengujian hipotesis sebagai berikut:

$\mathrm{H}_{0}$ : Tidak terjadi multikolinieritas

$\mathrm{H}_{1}$ : Terjadi Multikolinieritas

Berdasarkan nilai VIF dari variabel yang signifikan untuk persamaan kemiskinan, yaitu pengangguran dan IPM diperoleh masing-masing nilai VIF sebesar 1,284 < 10. Sementara itu, nilai VIF dari variabel yang signifikan untuk persamaan penganguran, yaitu kemiskinan dan jumlah penduduk masing- 
masing sebesar 9,978 $<10$. Dengan demikian, dapat disimpulkan bahwa $\mathrm{H}_{0}$ diterima yang berarti tidak terjadi multikolinieritas pada model simultan persamaan kemiskinan dan pengangguran.

c. Uji Heterokedastisitas

Uji heterokedastisitas digunakan untuk mengetahui apakah varian dari error bersifak konstan atau berubah-ubah. Model simultan dikatakan baik apabila errornya memupnyai varian yang konstan. Untuk uji hipotesis sebagai berikut:

$\mathrm{H}_{0}$ : Tidak terjadi heterokedastisitas

$\mathrm{H}_{1}$ : Terjadi heterokedastisitas

Berdasarkan output SPSS persamaan kemiskinan nilai $p$-value uji Glejser variabel pengangguran dan IPM sebesar $0,000<0,05$ dan nilai $p$-value variabel kemiskinan dan jumlah penduduk untuk persamaan pengangguran masing-masing sebesar 0,011 dan 0,232. Karena nilai $p$-value variabel eksogen pada persamaan kemiskinan $<0,05$ dapat disimpulkan $\mathrm{H}_{1}$ diterima, yang artinya pada persamaan kemiskinan terjadi heterokedastisitas. Sementara itu, nilai p-value variabel kemiskinan pada persamaan pengangguran $<0,05$, namun nilai $p$-value untuk variabel jumlah penduduknya > 0,05. Dengan demikian, dapat disimpulkan pada persamaan pengangguran $\mathrm{H}_{1}$ diterima yang berarti terjadi heterokedastisitas. Kesimpulannya adalah model simultan persamaan kemiskinan dan pengangguran terjadi heterokedastisitas.

\section{PENUTUP}

Berdasarkan hasil analisis dalam penelitian ini dapat disimpulkan bahwa model simultan persamaan kemiskinan dan pengangguran sebagai berikut:

$$
\begin{gathered}
Y_{1}=2,568 \times 10^{-15}+1,086 Y_{2}-0,451 X_{1}+\varepsilon_{1} \\
Y_{2}=1,681 \times 10^{-16}-0,590 Y_{1}+1,313 X_{2}+\varepsilon_{2}
\end{gathered}
$$

Hasil estimasi model simultan persamaan kemiskinan dan pengangguran dengan metode 2SLS menunjukkan bahwa variabel kemiskinan dipengaruhi oleh variabel pengangguran dan IPM. Sementara itu, variabel pengangguran dipengaruhi oleh kemiskinan dan jumlah penduduk. Hasil uji asumsi klasik model simultan menunjukkan bahwa persamaan kemiskinan dan pengangguran terjadi heterokedastisitas.

\section{DAFTAR PUSTAKA}

[1]. Badan Pusat Statistik (BPS). Provinsi Kalimantan Barat dalam Angka. Kalimantan Barat: Badan Pusat Statistik; 2000

[2]. Gujarati D. Ekonometrika Dasar. Jakarta: Erlangga; 2004

[3]. Pindyk S and Rubinfeld L. Econometric Models and Econometric Forecasts. Hill International Edition: Mc Graw; 1998

[4]. Gujarati D. Ekonometria Dasar, Terjemahan: Drs. Ak. Sumarno Zain, MBA. Jakarta: Erlangga; 2003

MISNO

EVY SULISTIANINGSIH
: Jurusan Matematika Fmipa Untan, Pontianak, misno992@gmail.com

: Jurusan Matematika Fmipa Untan, Pontianak, evysulistianingsih@math.untan.ac.id 